\title{
10 Xu thế lâm nghiệp trên thế giới Việt Nam cần xem xét trong quá trình xây dựng Chiến lược phát triển lâm nghiệp giai đoạn 2020-2030
}

Phạm Thu Thủy

Ngô Hà Châu

Nông Nguyễn Khánh Ngọc 

Báo cáo chuyên đề 256

\section{Xu thế lâm nghiệp trên thế giới Việt Nam cần xem xét trong quá trình xây dựng Chiến lược phát triển lâm nghiệp giai đoạn 2020-2030}

Pham Thu Thủy

Trung tâm Nghiên cứu Lâm nghiệp Quốc tế (CIFOR)

Ngô Hà Châu

Trung tâm Nghiên cứu Lâm nghiệp Quốc tế (CIFOR)

Nông Nguyễn Khánh Ngọc

Trung tâm Nghiên cứu Lâm nghiệp Quốc tế (CIFOR) 
Báo cáo chuyên đề 256

@ 2019 Tổ chức Nghiên cứu Lâm nghiệp Quốc tế (CIFOR)

(c) (i) Nội dung trong ấn phẩm này được cấp quyền bởi Giấy phép bản quyền Ghi nhận công của tác giả - Phi thương mại, không chỉnh sửa, thay đổi hay phát triển - Không phát sinh 4.0. http://creativecommons.org/ licenses/by-nc-nd/4.0/

DOI: $10.17528 /$ cifor/007489

Phạm TT, Ngô HC và Nông NKN. 2019. 10 Xu thế lâm nghiệp trên thế giới Việt Nam cân xem xét trong quá trình xây dựng Chiến lược phát triển lâm nghiệp giai đoạn 2020-2030. Báo cáo chuyên đề 256. Bogor, Indonesia: CIFOR.

\author{
CIFOR \\ JI. CIFOR, Situ Gede \\ Bogor Barat 16115 \\ Indonesia \\ $\mathrm{T}+62(251) 8622-622$ \\ $\mathrm{F}+62(251) 8622-100$ \\ E cifor@cgiar.org
}

\title{
cifor.org
}

Chúng tôi xin cảm ơn các nhà tài trợ đã hỗ trợ cho nghiên cứu này thông qua việc đóng góp vào quỹ của CGIAR. Xin xem danh sách các nhà tài trợ: http://www.cgiar.org/about-us/our-funders/

Tất cả các quan điểm thể hiện trong ấn phẩm này là của các tác giả. Chúng không nhất thiết đại diện cho quan điểm của CIFOR, các cơ quan chủ quản của tác giả hay của các nhà tài trợ cho ấn phẩm này. 


\section{Mục lục}

Lời cảm ơn $\quad$ iv

1 Mở đầu 1

2 Đô thị và những thành phố lâm nghiệp - Vai trò của ngành lâm nghiệp với ngành bất động sản

3 Tư duy mới cho ngành lâm nghiệp - Lâm nghiệp vì an sinh xã hội và đóng góp chủ lực cho ngành y tế

4 Ngành công nghiệp làm đẹp và mĩ phẩm từ lâm nghiệp và rừng 4

5 Ngành kinh doanh các loại côn trùng - xu thế mới trong khu vực và thế giới? 5

6 Mua bán phát thải, thương mại phát thải 6

7 Thuế và thuế giá trị gia tăng của hệ sinh thái rừng 7

8 Thị trường chứng khoán, cổ phiếu, trái phiếu rừng 8

9 Cách nhìn nhận, tiếp cận và đánh giá đầy đủ về lâm nghiệp, rừng và xoá đói giảm nghèo 10

10 Chuẩn bị cho Việt Nam sẵn sàng với luật chơi mới trên thị trường quốc tế sản xuất và kinh doanh không liên quan tới phá rừng và suy thoái rừng 12

11 Blue economy và Blue carbon/Kinh tế biển xanh và các-bon từ biển 13

12 Kết luận 14

$\begin{array}{ll}\text { Tài liệu tham khảo } & 15\end{array}$

\section{Danh sách hình và hộp}

Hộp

1 Phân bổ thuế hệ sinh thái để thúc đẩy bảo vệ, bảo tồn và phát triển rừng của chính phủ

Hình

1 Cấu trúc của Trái phiếu Rừng 


\section{Lời cảm ơn}

Nghiên cứu này là một hợp phần của Nghiên cứu so sánh toàn cầu về REDD+ mà CIFOR đang tiến hành về REDD+ (www.cifor.org/gcs). Chúng tôi xin trân trọng cảm ơn hỗ trợ tài chính từ các nhà tài trợ bao gồm Cơ quan Hợp tác Phát triển Na Uy (NORAD), Cơ quan phát triển Mỹ (USAID) và Chương trình nghiên cứu CGIAR về rừng, cây và nông lâm kết hợp (CRP-FTA), đã hỗ trợ nghiên cứu này. 


\section{Mở đầu}

Các quốc gia trong khu vực Châu Á Thái Bình Dương, trong đó có Việt Nam, đang trong quá trình xây dựng chính sách phát triển ngành lâm nghiệp trong giai đoạn tới 2020 - 2030. Trong quá trình hình thành xây dựng cơ chế mới này, mọi quốc gia đều cần phải cập nhật và đón đầu xu thế phát triển mới trên thế giới. Việt Nam hiện cũng đang xây dựng các chính sách mới trong giai đoạn tới, bao gồm Chiến lược phát triển lâm nghiệp Việt Nam, thực hiện chính sách tái cơ cấu ngành, xem xét sửa đổi đóng góp của ngành lâm nghiệp vào cam kết tự nguyện quốc gia (NDC). Tóm lược chính sách này rà soát các tài liệu hiện có của nhiều quốc gia trên thế giới, các báo cáo phát triển toàn cầu nhằm cung cấp các thông tin cập nhật trên toàn cầu và thảo luận các vấn đề cần xem xét trong bối cảnh của Việt Nam. Tài liệu này không thảo luận các vấn đề mà các báo cáo chuyên sâu khác đã đề cập đến, bao gồm xu thế dân số, áp lực và tác động của biến đổi khí hậu, năng lượng tái tạo, rủi ro tài chính, mà chỉ tập trung vào các xu thế lâm nghiệp phát triển trong giai đoạn tới. Trước bối cảnh huy động nguồn tài chính bền vững cho ngành lâm nghiệp đang trở thành một trong những ưu tiên chính của ngành, việc tiếp cận với các xu thế mới cũng sẽ giúp chính phủ mở rộng tiềm năng tài chính cho ngành hiệu quả hơn. 


\section{2 Đô thị và những thành phố lâm nghiệp - Vai trò của ngành lâm nghiệp với ngành bất động sản}

Khái niệm đô thị lâm nghiệp lần đầu tiên được thảo luận trên thế giới vào năm 1894 tại Mỹ và được hiện thực hóa vào những năm 1960 khi hội đồng khoa học Mỹ chính thức công nhận đây là một ngành nghiên cứu khoa học liên ngành (Konijnendijk và cộng sự 2006). Tại các bang ở Mỹ, lâm nghiệp đô thị trở thành một ngành chủ lực tạo ra nguồn thu cho ngân sách bang từ các khóa học đào tạo cho công chúng và những người quan tâm biết cách trồng cây lâm nghiệp phù hợp trong việc tạo cảnh quan lâm nghiệp tại các khu chung cư, đô thị, cấp chứng chỉ hành nghề cho các tổ chức và cá nhân để hoạt động trong lĩnh vực cảnh quan môi trường đô thị. Lâm nghiệp đô thị sau này trở thành một khái niệm và ngành nghề ngày càng phát triển tại $M y ̃$, mở rộng sang Châu Âu và gần đây là các nước trong khu vực Châu Á Thái Bình Dương.

Tại Trung Quốc, lâm nghiệp đô thị trở thành khái niệm buộc phải làm đối với cảnh quan đô thị (FAO 2019). Chương trình thành phố rừng và lâm nghiệp quốc gia đã được phát động vào năm 2004, giúp gia tăng tỉ lệ che phủ cây rừng trong thành phố tăng từ 10\% năm 1981 lên đến lên trên 40\%. Tính tới thời điểm cuối năm 2018, 138 thành phố tại Trung Quốc đã được chứng nhận là thành phố rừng quốc gia và Trung Quốc đặt mục tiêu sẽ có tới 300 thành phố rừng vào năm 2025 (FAO 2019). Để đạt được chứng nhận là thành phố rừng/thành phố lâm nghiệp, một thành phố sẽ phải trải qua các quá trình đánh giá, chứng minh và thẩm định dựa trên 38 tiêu chuẩn và tiêu chí trong 3 lĩnh vực: tổ chức hành chính và vận hành; hệ thống quản lí; và phát triển rừng.

Năm 2007, Hàn Quốc công bố chương trình Kế hoạch lâm nghiệp đô thị với tầm nhìn "Thành phố trong rừng và rừng trong thành phố" với mục tiêu cải thiện chất lượng sống tại đô thị bằng việc thiết lập một mạng lưới lâm nghiệp đô thị bao gồm cây trên phố, các trường lâm nghiệp, các công viên lâm nghiệp và cảnh quan lâm nghiệp để tăng chỉ số xanh của cây lên từ $9.91 \mathrm{~m}^{2} /$ người năm 2015 lên đến $15 \mathrm{~m}^{2} /$ người (FAO 2019). Malaysia cũng đang ra mục tiêu sẽ trở thành quốc gia vườn xanh vào năm 2020. Nghiên cứu về xu thế phát triển lâm nghiệp của khu vực Châu Á Thái Bình Dương của FAO (2019) chỉ rõ việc áp dụng và mở rộng cảnh quan lâm nghiệp và lâm nghiệp đô thị đã giúp ngành bất động sản của Hồng Kông và Quảng Châu, Trung Quốc có giá trị nhảy vọt.

Mục tiêu của chương trình Toàn cầu về cây xanh trong thành phố đã được công bố năm 2018 như một phần quan trọng để thực hiện mục tiêu thiên niên kỉ (FAO 2019). Tại Việt Nam, khu đô thị sinh thái Ecopark cũng là một ví dụ điển hình của việc kết hợp cảnh quan sinh thái để hấp dẫn người mua và đã chứng tỏ được vị thế của mình. Với tốc độ đô thị hóa ngày càng nhanh tại Việt Nam, bắt kịp xu thế thời đại về lâm nghiệp đô thị, tạo ra các ngành nghề mới phù hợp với yêu cầu thị trường và thực tế phát triển đô thị tạo đi hướng đi mới cho ngành lâm nghiệp. 


\section{Tư duy mới cho ngành lâm nghiệp - Lâm nghiệp vì an sinh xã hội và đóng góp chủ lực cho ngành y tế}

Trước năm 1980, ngành lâm nghiệp trên toàn cầu tập trung vào việc nâng cao sản lượng gỗ và lâm sản. Tuy nhiên, từ năm 2005 trở lại đây, xu thế phát triển của ngành lâm nghiệp trên toàn cầu đã thay đổi và định hướng lâm nghiệp là một ngành đóng góp chủ lực vào an sinh xã hội. Theo FAO (2019), vào những năm 1980, người Nhật đã đưa vào cuộc sống khái niệm shinrin-yoku (tắm rừng). Nhóm bác sĩ tâm lí trị liệu rừng được thành lập bao gồm các cơ quan chính phủ, các tổ chức nghiên cứu hàn lâm đã tiến hành hoạt động này tại thành phố liyama vào năm 2005. Nhóm bác sĩ này đã đưa 12 người đàn ông trung niên tới rừng và tắm rừng trong 3 ngày và đã chỉ ra rằng chuyến đi tắm rừng đã giúp họ nâng cao khả năng miễn dịch, năng lượng, giảm các lo lắng, trầm cảm và tức giận. Sau đó, thành phố liyama đã cấp chứng chỉ chữa bệnh tâm lí trị liệu rừng đầu tiên tại Nhật Bản và chính thức công nhận rừng có tác dụng đặc biệt trong việc chữa trị vật lí trị liệu (FAO 2019). Từ đó, các nghiên cứu khoa học cơ bản đã được thực hiện nhiều hơn ở Nhật Bản nhằm hiểu rõ giá trị và vai trò của rừng, và chỉ ra rằng rừng giúp chất lượng ngủ tốt hơn. Hiện nay tại Nhật Bản có 62 cơ sở nghiên cứu trị liệu liên quan đến rừng và có 2.5- 5 triệu người đi dạo trong rừng theo chỉ định của bác sĩ để giảm stress và chăm sóc sức khỏe của họ (Association of Nature and Forest Therapy Guides and Programs).

Học tập theo Nhật Bản, Hàn Quốc cũng đang xây dựng mà mở rộng các biện pháp tâm lí trị liệu trên cả nước. Quốc gia này có kế hoạch xây dựng 34 cơ sở chữa bệnh từ rừng, và đào tạo 500 hướng dẫn viên và bác sĩ chữa bệnh từ rừng để cung cấp các dịch vụ này cho công chúng. Vụ Lâm Nghiệp Hàn Quốc cũng đầu tư hàng triệu đô la để tiến hành các nghiên cứu với nhiều ngành khoa học cơ bản khác nhau về vai trò của rừng trong việc chữa bệnh và Quốc Hội đã thông qua Luật đẩy mạnh rừng trong việc bảo vệ sức khỏe con người (International Society of Nature and Forest Medicine 2015). FAO (2019) cũng rà soát các báo cáo quốc gia trong khu vực Châu Á Thái Bình Dương và cho thấy ngành lâm nghiệp cũng đóng góp cho ngành y tế bởi các số liệu nghiên cứu khoa học đã chứng minh được nếu bệnh nhân ở các bệnh viện đóng ở chỗ có nhiều cây xanh sẽ khỏi bệnh nhanh hơn so với các bệnh viện ở chỗ đông người và ít cây xanh.

Hiện nay trên thế giới đã có Hiệp Hội toàn cầu về thiên nhiên và Vật lí trí liệu của Rừng và Hiệp Hội này đã xây dựng các Hướng dẫn về vật lí trị liệu dựa vào rừng, dựa trên các nghiên cứu lâu năm về mối liên kết chặt chẽ giữa rừng và sức khỏe. Từ đó, hơn 44 quốc gia trên toàn cầu đã xây dựng gần 700 hướng dẫn về chủ đề này trên toàn cầu (Association of Nature and Forest Therapy Guides and Programs, Global Institute of Forest Therapy). Ngay cả Châu Âu và Anh Quốc cũng xây dựng các viện nghiên cứu về phương pháp chữa bệnh và vật lí trị liệu nhờ rừng (The European Forest Therapy Institute, Nature and Therapy UK). Ngành lâm nghiệp tại các nước cũng chuyển mình để đào tạo các kiểm lâm viên trở thành những bác sĩ vật lí trị liệu và người hướng dấn về sức khỏe. Tại Hàn Quốc, các kiểm lâm sẽ được đào tạo và cấp chứng chỉ sau 4 tháng để trở thành người hướng dẫn trị liệu tại các khu vực rừng mà họ đang quản lí. Mỗi khách tới thăm, ngoài việc trả phí vào cửa cho Vườn Quốc Gia hay khu bảo tồn thì sẽ phải trả 4-8 USD/giờ/người để có thể được chữa trị vật lí trị liệu từ rừng. Tại Mỹ, khóa học này dài hơn và có thể dài tới 6 tháng với mức phí học là 3570 USD/khóa học (Association of Nature and Forest Therapy Guides and Programs, Forest Therapy Guide Training Southern California-Spring 2020). Việt Nam cần xem xét xu thế định hướng đang ngày lan rộng trên toàn thế giới này để có những chính sách và chiến lược phù hợp. 


\section{Ngành công nghiệp làm đẹp và mĩ phẩm từ lâm nghiệp và rừng}

Theo FAO (2019), thị trường các sản phẩm mĩ phẩm và làm đẹp đã phát triển với mức tăng trưởng 4\% hàng năm chỉ trong vòng 10 năm (2000 - 2010), với trị giá hàng hóa bán tăng mạnh từ 382 tỉ USD năm 2010; và dự đoán sẽ tăng lên 675 tỉ USD vào năm 2020 và 717 tỉ USD năm 2025 (Loboda and Lopaciuk 2013). Nhu cầu về mĩ phẩm gia tăng là do phụ nữ tham gia lực lượng lao động ngày càng nhiều, và quan điểm về các sản phẩm mĩ phẩm ngày càng thay đổi theo hướng thân thiện với môi trường và có nguồn gốc tự nhiên. Không những vậy, xu thế hiện nay còn tăng mạnh đối với các sản phẩm mĩ phẩm cho nam giới và trẻ em. Các sản phẩm làm đẹp đến từ rừng như mật ong rừng, bột thanaka (Murraya spp.) chống nắng, gỗ sandalwood oil được sử dụng làm hương liệu bán chạy và có lượng người dùng lớn. Các thương hiệu lớn về mĩ phẩm trên thế giới đều có những nghiên cứu chiết xuất các hương liệu có nguồn gốc từ rừng nhiệt đới, và các nhãn hiệu gắn liền với các khu rừng nguyên sinh như Amazon lại bán chạy nhất trên thế giới. Đón nhận xu thế này và mở rộng các hoạt động nghiên cứu, đầu tư cho lĩnh vực này cũng nên được xem xét bởi chính phủ Việt Nam. 


\section{Ngành kinh doanh các loại côn trùng - xu thế mới trong khu vực và thế giới?}

Thức ăn từ các loại côn trùng ngày càng trở thành món ăn được yêu thích trong khu vực Châu Á Thái Bình Dương. Thức ăn từ côn trùng đảm bảo các yếu tố môi trường, bên cạnh đó các loại côn trùng cũng được cho rằng có giàu chất protein, các loại vitamin tự nhiên và khoáng chất, và không có ảnh hưởng đến môi trường. Bắt kịp xu thế này, Thái Lan đã xây dựng và phát triển thị trường này một cách rõ rệt. Chỉ trong có vài năm gần đây, đã có hơn 20,000 doanh nghiệp kinh doanh và sản xuất các mặt hàng liên quan đến sản xuất thức ăn côn trùng. Ngành nghề này đang tạo ra lợi nhuận lên tới hàng triệu USD và cung cấp việc làm và thu nhập cho hàng nghìn người (FAO 2019). 


\section{Mua bán phát thải, thương mại phát thải}

Thị trường mua bán và thương mại phát thải đã được hình thành nhiều nơi trên thế giới, nhưng có lẽ phát triển nhất là 5 cơ chế và thị trường phát thải của Cộng đồng Châu Âu, Hàn Quốc, tỉnh Quảng Đông của Trung Quốc, Ontario và Quebec của Canada, và California của Mỹ. Xây dựng cơ chế và thị trường mua bán phát thải thương mại luôn được coi là một chính sách quan trọng của các quốc gia trong cuộc chiến đối mặt với biến đổi khí hậu.

Tại Califonia, thương mại phát thải được áp dụng với các công ty nhiệt điện, các khu công nghiệp lớn, các nhà máy sản xuất xi măng, dầu, gas, thủy tinh, điện lưới, các chuỗi cung ứng và bán dầu nhiên liệu. Khoảng 450 doanh nghiệp sản xuất 85\% lượng phát thải tại California buộc phải tuân thủ chính sách này. Các công ty trong bang hoặc ngoài bang có thể bồi hoàn tín chỉ giảm phát thải thông qua việc mua từ các công ty khác. Mua bán thương mại phát thải cũng tạo ra các thị trường và ngân sách từ việc đấu giá và do vậy có thể tái đầu tư vào các hoạt động giảm phát thải khác (Pacific Forest Trust). Các công ty phải mua giấy phép hoạt động hoặc hạn ngạch (quota) từ nhà nước cho từng tấn $\mathrm{CO}_{2}$ họ phát thải ra. Số lượng giấy phép hoặc quota bị hạn chế (cap) và sẽ giảm dần theo các năm theo định hướng và cam kết phát thải của nhà nước. Các công ty được phép bán quota mà họ mua (trade), và họ sẽ cố gắng giảm phát thải dưới hạn mức mà họ đã mua nhằm có thể bán các quota còn thừa (Zwick n.d.). Các công ty cũng có một lựa chọn khác đó là thay thế một phần nhỏ hạn mức cho phép của mình bằng cách bồi hoàn phát thái. Bồi hoàn phát thải là giảm phát thải ngoài ngành bị ra quy định để đảm bảo cam kết ràng buộc về trách nhiệm giảm phát thải của các công ty. Ví dụ, Bộ tộc Yurok tại Bắc California quản lí và bảo vệ rừng rốt, sau khi được bên thứ 3 thẩm định đã bán được 800,000 tín chỉ các-bon từ rừng của họ cho một công ty buộc phải cam kết giảm phát thải tại California (Zwick n.d.).

Hiện nay, California đã tiếp tục kí thỏa thuận hợp tác với Brazil và Mexico để các doanh nghiệp có thể bồi hoàn phát thải từ việc giảm phát thải từ phá rừng và suy thoái rừng và tiến hành chi trả cho toàn ngành nông lâm nghiệp chứ không chỉ tập trung vào các dự án quy mô nhỏ. Chương trình bồi hoàn phát thải quốc tế theo ngành của Califorinia không tập trung vào các dự án mà trên toàn cảnh quan vùng. Đây là cơ chế tài chính mới mà thế giới đang kì vọng có thể tạo nguồn thu mới cho bảo vệ và phát triển rừng, cũng như giảm phát thải mà vẫn đảm bảo các biện pháp đảm bảo an toàn cả về môi trường lẫn xã hội (Zwick n.d.). 


\section{Thuế và thuế giá trị gia tăng của hệ sinh thái rừng}

Để giảm phát thải và bảo vệ và bảo tồn rừng, nhiều quốc gia đã xây dựng chính sách ấn định thuế và thuế giá trị gia tăng của hệ sinh thái rừng. Nổi bật nhất trên thế giới là chính sách ấn định thuế của Brazil và Ấn Độ, trong đó xác định diện tích, độ che phủ và chất lượng rừng là một tiêu chí quan trọng để phân bổ nguồn ngân sách nhà nước thu được từ thuế (Hộp 1).

\section{Hộp 1. Phân bổ thuế sinh thái để thúc đẩy bảo vệ, bảo tồn và phát triển rừng của chính phủ}

Năm 2014, Ấn Độ triển khai chính sách phẩn bổ nguồn thuế tài chính cho hệ sinh thái để bảo vệ và bảo tồn rừng theo đề xuất của Ban kinh tế trung ương. 5 năm 1 lần, Ủy Ban kinh tế trung ương sẽ xác định các tiêu chí có thể đo đếm được để phân bổ nguồn thuế từ Trung ương như gia tăng dân số, tỉ lệ đói nghèo, phân bổ khu vực, năng lực quản lí tài chính. Năm 2014, Ban kinh tế trung ương bổ sung thêm tiêu chí diện tích rừng là một trong những tiêu chí để phân bổ ngân sách nhà nước và tiêu chí này chiếm tới $7.5 \%$ tiêu chí phân bổ. Con số này được tính toán dựa trên lập luận rằng nhà nước phải đền bù cho các chi phí cơ hội của công tác bảo tồn rừng. Kết quả điều tra để đánh giá tỉ lệ che phủ rừng được tiến hành vào năm 2013 sẽ được sử dụng để phân bổ ngân sách. Bang nào bảo vệ và bảo tồn rừng tốt hơn, sẽ nhận được nhiều tiền phân bổ từ ngân sách hơn, từ đó tạo ra cơ chế khuyến khích để các bang trồng mới và tái sinh rừng. Số tiền phân bổ này hàng năm trong giai đoạn 2015- 2020 theo cơ chế này sẽ dao động từ 6.9-12 tỉ USD (khoảng 174-303 USD/ha/năm). Tuy chưa có đánh giá cụ thể và tác động của cơ chế này, báo cáo tài nguyên năm 2017 đã ghi nhận những thay đổi tích cực. Ban kinh tế trung ương nhiệm kì 15 hiện đang rà soát lại cơ chế này để tiếp tục áp dụng cho giai đoạn 2020-2025 (Busch and Mukherjee 2017). 


\section{Thị trường chứng khoán, cổ phiếu, trái phiếu rừng}

Dự đoán sự khan hiếm và phát triển của các dịch vụ môi trường trong tương lai, nhiều quốc gia đã xây dựng thị trường chứng khoán, cổ phiếu và trái phiếu rừng. Trong đó nổi bật nhất có lẽ là Chile khi trong có vài năm đã giao dịch gần 13 triệu USD trái phiếu rừng. Các trái phiếu này được các nhà đầu tư lớn như Quỹ hưu trí, các ngân hàng và các công ty bảo hiểm mua. Khi bán các trái phiếu này, tiền thu được sẽ được sử dụng để mua các cây non mới trồng và chi trả cho phí quản lí và tái sinh rừng tại các khu vực này. Các nhà đầu tư có thể mua lại các rừng mới trồng, các rừng non mà nếu không có người mua sẽ bị chặt bỏ và đầu tư vào những diện tích rừng trồng đó. Khi đầu tư như vậy cả người sỡ hữu trái phiếu và chủ rừng sẽ cùng chia sẻ lợi nhuận trong việc quản lí và bảo vệ diện tích rừng này (Ministry of Finance - The Republic of Chile 2019).

Mô hình chứng khoán, cổ phiếu và trái phiếu liên quan đến rừng được thảo luận nhiều nhất hiện nay trong cộng đồng đầu tư trên thế giới là Trái phiếu rừng của Tập đoàn tài chính quốc tế (IFC). Trái phiếu IFC được tạo ra nhằm hướng dòng vốn vào những dự án tư nhân tuân theo khuôn khổ chương trình giảm phát thải từ rừng và suy thoái rừng $(R E D D+)$ để khuyến khích tài chính và đầu tư vào tăng trưởng các-bon thấp. Vào tháng 10 năm 2016, IFC đã phát hành trái phiếu rừng đầu tiên và huy động được 152 triệu USD (IFC, Forest Bond). Khi tham gia vào thị trường trái phiếu rừng, các nhà đầu tư sẽ nhận trái tức (coupon). Có bốn hình thức trái tức cho các nhà đầu tư có thể lựa chọn (IFC 2016a):

- tiền mặt;

- một phần tiền mặt và phần còn lại dạng tín dụng các-bon;

- tín dụng các-bon và "kết thúc" quyền phát thải của tín dụng (retire) để bồi hoàn phát thải khí nhà kính;

- tín dụng các-bon và bán chúng trên thị trường các-bon.

Tín dụng các-bon có thể hiểu là một chứng chỉ hoặc giấy phép có thể mua bán được đại diện cho quyền được phát thải 1 tấn $\mathrm{CO}_{2}$ hoặc khối lượng của một loại khí nhà kính khác tương đương với 1 tấn $\mathrm{CO}_{2}$. Nhà đầu tư chọn trái tức tín dụng các-bon có thể "kết thúc" quyền phát thải của tín dụng để bồi hoàn phát thải khí nhà kính doanh nghiệp của mình , tức chấm dứt việc tiếp tục lưu hành của trái phiếu đó trên thị trường, hoặc bán chúng trên thị trường các-bon (IFC 2016a). Tại Kenya, trái tức dự kiến sẽ hỗ trợ cho việc bảo tồn rừng và đưa ra một lựa chọn cho chuyển giao tín chỉ REDD+ cho các chủ trái phiếu. Dự án được hỗ trợ cũng được kỳ vọng sẽ giảm phá rừng, bảo vệ các loài động thực vật đang bị đe dọa, và phát triển kinh tế bền vững cho cộng đồng ở Kenya.

Hình 1 thể hiện hệ thống xây dựng và quản lí của trái phiếu các-bon IFC với trường hợp lợi tức tiền mặt với tùy chọn một phần hoặc toàn bộ trái tức có thể chuyển giao được trong các đơn vị các-bon đã thẩm tra được ( 5 năm với thương phiếu 150 triệu đô la). Trình tự của quy trình phát hành trái phiếu rừng như sau:

1. Vào ngày phát hành, các nhà đầu tư trong thương phiếu (notes) sẽ trả tổng cộng đến 150 triệu USD cho IFC dạng tiền thu phát hành, với sự xem xét việc phát hành thương phiếu.

2. Người giữ thương phiếu (noteholders) sẽ nhận thường niên một khoản trái tức tiền mặt cố định trong đó một phần hoặc toàn phần trái tức có thể chuyển giao được trong các đơn vị các-bon đã thẩm tra (VCUs) cho mỗi thương phiếu tại mức giá cố định là 5 USD mỗi VCU.

3. Bên cạnh khả năng kết thúc quyền phát thải của VCU trong lưu hành, người giữ thương phiếu có thể bán chúng một cách độc lập cho thị trường VCU.

4. IFC sẽ mua các VCU được tạo ra bởi dự án trên cơ sở hằng năm. 
Hình 1. Cấu trúc của Trái phiếu Rừng

Nguồn: IFC 2016b

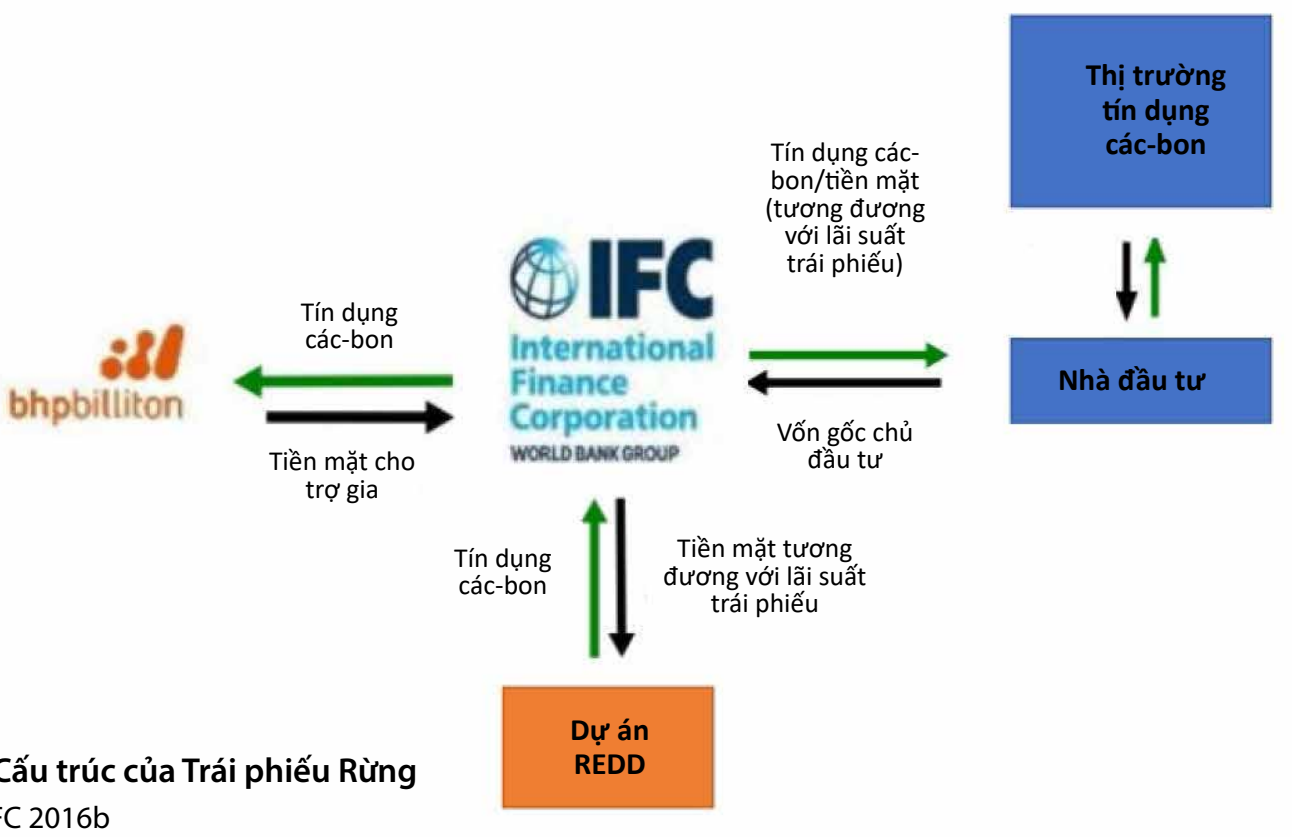

5. Đối với mỗi ngày thanh toán lãi tức, IFC sẽ sử dụng các VCU mua được từ dự án để đáp ứng nhu cầu của nhà đầu tư đối với việc giao VCU thực tế, và tổ chức sẽ đưa vào tập đoàn BHP Billiton ${ }^{1}$ tất cả các VCU chưa sử dụng, tức số lượng các VCU mà người giữ thương phiếu chưa được chọn để nhận.

6. Các nhà đầu tư không phải đối mặt với bất kỳ rủi ro tín dụng hoặc rủi rỏ kết quả hoạt động nào của BHP Billiton.

7. Tổng giá trị tiền mặt của hỗ trợ giá cung cấp bởi BHP Billiton sẽ được ký quỹ vào hoặc trước ngày phát hành thương phiếu. Nếu bất kỳ phần nào hoặc tất cả giá hỗ trợ hàng năm bởi BHP Billiton dưới Quyền Chọn bán (Put Option) không được sử dụng, thì BHP Billiton có thể, thông qua IFC, áp dụng phần còn lại để mua VCU từ dự án cho tài khoản riêng của BHP Billiton.

Theo IFC (2016b), trái phiếu rừng có giá trị và hấp dẫn với nhà đầu tư bởi:

- sẽ giúp công ty bồi hoàn phát thải nhà kính của doanh nghiệp thông qua việc trực tiếp đầu tư vào bảo vệ rừng;

- có đầy đủ sự bảo vệ và bảo đảm về mặt tài chính lâu dài;

- không phát sinh thêm chi phí thẩm định dự án được hỗ trợ bởi trái phiếu rừng;

- khả năng được nhận lãi tức dưới dạng tín chỉ các-bon được phát hành từ dự án REDD+

- khả năng đa dạng hồ sơ đầu tư trách nhiệm xã hội;

- lợi nhuận xã hội và môi trường có thể đo lường được dự kiến từ đánh giá và thẩm định dự án được hỗ trợ hằng năm;

- các dự án thường được yêu cầu phải đạt được các tiêu chuẩn nghiêm ngặt của IFC về môi trường, xã hội và quản trị cũng như Tiêu chuẩn kiểm chứng các-bon tự nguyện (VCS) và đẳng cấp vàng (Gold) của Tiêu chuẩn Khí hậu, Cộng đồng và Đa dạng sinh học (CCB);

- giá lãi tức tiền mặt phù hợp với đường cong lãi suất giản đơn của IFC.

1 BHP Billiton là tập đoàn khai thác mỏ, thép và dầu khí đa quốc gia. IFC phát triển Trái phiếu Rừng cùng với tập đoàn BHP Billition, và tổ chức bảo tồn quốc tế Conservation International. BHP Billiton cung cấp một thỏa thuận hỗ trợ giá để đảm bảo rằng dự án sẽ bán một lượng đơn vị VCU tối thiểu mỗi năm cho đến khi Trái phiếu Rừng IFC đáo hạn. Các dự án REDD thường phải bán một lượng VCU nhất định mỗi năm để được bền vững (BHP Billiton 2016). 


\section{Cách nhìn nhận, tiếp cận và đánh giá đầy đủ về lâm nghiệp, rừng và xoá đói giảm nghèo}

Trên thế giới nói chung và Việt Nam nói riêng, ngành lâm nghiệp luôn kì vọng sẽ đóng góp tích cực vào công cuộc xóa đói giảm nghèo. Tuy nhiên, một câu hỏi được đặt ra là tại sao ở nơi nào có nhiều rừng nhất lại là nơi có nhiều người nghèo nhất. Các bên liên quan thậm chí đặt câu hỏi "Liệu có phải vì có nhiều rừng nên người dân nghèo?". Việc trả lời các câu hỏi này bằng kết quả nghiên cứu khoa học sẽ xác định lại đúng vị thế và vai trò của lâm nghiệp trong bối cảnh phát triển kinh tế xã hội của quốc gia.

Hiện nay, khi nói về việc đóng góp của lâm nghiệp vào xóa đói giảm nghèo, các bên mới chỉ nghĩ đến việc ngành lâm nghiệp đóng góp vào thu nhập của người nghèo là bao nhiêu. Quan niệm và góc nhìn hạn hẹp này vừa không thể hiện đầy đủ khái niệm đói nghèo vừa không đánh giá tầm quan trọng của lâm nghiệp trong việc xóa đói giảm nghèo.

Nghèo đói là một khái niệm có nhiều khía cạnh. Định nghĩa về nghèo đói đã thay đổi nhanh chóng và thay đổi theo thời gian. Các quốc gia trên thế giới không còn đánh giá nghèo đói theo mặt thu nhập và của cải vật chất, mà bao gồm nhiều mặt (bao gồm các khía cạnh phi vật chất của cuộc sống con người, như dinh dưỡng và an ninh lương thực, y tế, giáo dục, kiểm soát và an ninh, trao quyền, cơ hội tiếp cận với tài nguyên và tự do lựa chọn) (World Bank 2000; Angelsen và Wunder 2003). Chính vì vậy, khi thảo luận và nhìn nhận về vai trò của rừng và lâm nghiệp trong xóa đói giảm nghèo cũng cần phải nhìn trên đa phương diện.

Cải thiện, đa dạng sinh kế và tránh rủi ro trong các điều kiện bất thường. Rừng có vai trò quan trọng cho người nghèo trong việc duy trì cuộc sống (Byron và Arnold 1999, Angelsen và Wunder 2003, Vedeld và cộng sự 2004) và trong một số trường hợp là nguồn cải thiện thu nhập (ví dụ, Ruíz-Pérez và cộng sự 2004). Trên thế giới, nguồn thu từ lâm nghiệp đóng góp trung bình khoảng $28 \%$ tổng thu nhập của người dân. Việc đa dạng hóa các nguồn thu nhập rất quan trọng đối với người nghèo ở nông thôn như là một biện pháp để giảm thiểu rủi ro (Ellis 2000). Tài nguyên rừng cung cấp một nguồn thu nhập lấp đầy khoảng thời gian trống giữa các vụ thu hoạch nông nghiệp và là mạng lưới an toàn trong trường hợp thiên tai, nạn đói, lũ lụt, bão hoặc chiến tranh (Angelsen và Wunder 2003, Takasaki và cộng sự 2004). Rừng có thể là một hình thức tiết kiệm (Chambers và cộng sự 1993) và là một hình thức bảo đảm cuộc sống từ thiên nhiên (Pattanayak và Sills 2001, McSweeney 2004). Tại Việt Nam, nhiều khảo sát của CIFOR tại các vùng núi cho thấy người giàu chủ yếu đầu tư vào trồng rừng vì họ coi đó là một khoản đầu tư lâu dài cho con cái của họ. Khai thác gỗ và công nghiệp gỗ, mặc dù luôn được coi ngành khó tiếp cận đối với người nghèo vì lợi nhuận rơi vào những bên có nguồn lực tài chính, cũng có thể giúp giảm nghèo. Khai thác đòi hỏi vốn, kỹ năng, quyền sử dụng đất, công nghệ, hệ thống sản xuất và thời gian khai thác lâu mà chỉ những bên có nguồn lực mới có (Angelsen và Wunder 2003,34). Bên cạnh việc phân bổ quyền kinh tế không đồng đều, về mặt kinh tế, giá trị sản phẩm gỗ giảm dưới sự khai thác người nghèo. Tuy nhiên, việc tái đầu tư lợi nhuận từ gỗ vào các lĩnh vực khác của nền kinh tế, phát triển lâm nghiệp của đất nước, tác động tích cực đến giá lâm sản đô thị, và tác động phát triển đến cộng đồng địa phương (cơ sở hạ tầng) có thể gián tiếp mang lại lợi ích cho toàn xã hội, bao gồm người nghèo (Angelsen và Wunder 2003,32,34). 
Ngoài thu nhập từ gỗ và lâm sản ngoài gỗ, người nghèo có thể hưởng lợi từ chi trả dịch vụ môi trường rừng (PFES) (Angelsen và Wunder 2003,34). Nghiên cứu của Phạm và cộng sự (2019) chỉ rõ chương trình PFES tại Việt Nam ưu tiên chi trả cho nhóm người nghèo, và trên thực tế tại nhiều địa phương, trên $90 \%$ người nghèo của thôn bản được tham gia và hưởng lợi từ PFES. Nguồn thu PFES đã giúp họ đảm bảo lương thực để sống qua ngày.

Cung cấp và giảm các chi phí dịch vụ y tế cho người nghèo. Nhiều nghiên cứu trên toàn thế giới đã chỉ rõ một người nghèo sống ở thành thị có thể có thu nhập cao hơn ở nông thôn hoặc một người dân tộc thiểu số. Tuy nhiên, khi họ bị bệnh, họ sẽ phải trả các chi phí cho khám chữa bệnh tại thành phố khá đắt đỏ. Trong khi đó, tại các vùng có rừng, rừng cung cấp nhiều sản phẩm và dịch vụ miễn phí từ thiên nhiên (Anderson và cộng sự 1991) dưới dạng thực phẩm, nhiên liệu và thuốc (Byron và Arnold 1999, Hickey và cộng sự 2016). Các sản phẩm lâm sản ngoài gỗ và khai thác gỗ cũng đóng góp quan trọng vào thu nhập của người dân địa phương.

Điều kiện an sinh và tiếp cận với tài nguyên. Tại sao nơi nghèo nhất lại là nơi có nhiều rừng nhất ? Nghiên cứu trên toàn cầu đã chỉ rõ người nghèo hoặc người yếu thế thường tìm đến vùng có nhiều rừng để tìm đất canh tác bởi họ không thể tiếp cận được với đất đai ở những nơi phát triển do đất ở các nơi này thường đắt đỏ và nằm trong tay của nhóm có quyền lực. Với đặc tính tự do tiếp cận (open-access) các khu vực rộng ở rừng công cộng ở các nước đang phát triển, và việc các diện tích rừng thường ở nơi hẻo lánh, nơi thực thi pháp luật thường không hiệu quả, người nghèo thường xuyên được đảm bảo rằng không bị cản trở trong việc sử dụng tài nguyên rừng (Sunderlin và cộng sự 2008). Điều này cũng xảy ra trong bối cảnh của Việt Nam khi các cộng đồng dân tộc thiểu số di dân trên các vùng núi của Điện Biên, Lai Châu để tìm đất canh tác. Rừng đã giúp họ có đất nông nghiệp mới, phục hồi độ phì nhiêu của đất trên đất hoang được sử dụng trong chu kỳ canh tác nương rẫy, có nguồn vật liệu xây dựng nhà cửa, và tiếp cận với nước ngọt thông qua chức năng rừng đầu nguồn (Sunderlin và cộng sự 2008).

Xóa đói giảm nghèo cụ thể gì ? Khi xây dựng chính sách lâm nghiệp hướng tới giảm nghèo và đánh giá đóng góp của ngành tới xóa đói giảm nghèo Angelsen và Wunder (2003) cho rằng xóa đói giảm nghèo bao gồm 2 khía cạnh:

- Giảm nghèo là các đóng góp và hoạt động của ngành lâm nghiệp giúp người đân nâng cao điều kiện sống tốt hơn theo thời gian, theo nghĩa tuyệt đối (không có đủ điều kiện sinh sống) hoặc tương đối (bất bình đẳng trong thu nhập và điều kiện sống).

- Chống đói nghèo mô tả vai trò của rừng trong việc giúp mọi người duy trì mức sống tối thiểu và giúp họ sống sót. Chống đói nghèo đảm bảo rằng các điều kiện của mọi người sẽ không trở nên tồi tệ hơn nhưng cũng không cải thiện tình trạng đói nghèo.

Do vậy phát triển rừng vì người nghèo (pro-poor) hiệu quả đòi hỏi cả việc tăng giá trị gia tăng của sản phẩm cũng như đảm bảo phần thu nhập của người nghèo không bị giảm. Phát triển khung chính sách hỗ trợ người nghèo cũng cần có có các chính sách và chương trình, bồi dưỡng kỹ năng, kế hoạch tiếp thị và giảm đi vai trò của người trung gian là một trong những yếu tố tối cần thiết để đạt được mục tiêu này (Arnold 2001). 


\section{Chuẩn bị cho Việt Nam sẵn sàng với luật chơi mới trên thị trường quốc tế - sản xuất và kinh doanh không liên quan tới phá rừng và suy thoái rừng}

Sản xuất và kinh doanh không liên quan đến phá rừng là yêu cầu của thị trường toàn cầu từ nay tới năm 2030. Hơn 1000 thể chế tài chính (ví dụ: ngân hàng, quỹ ủy thác, nhà tài trợ), và 600 tập đoàn đa quốc gia trên toàn cầu đã cam kết sản xuất và cung cấp các sản phẩm nông sản không liên quan đến phá rừng và đang xây dựng quy trình kiểm tra, sàng lọc, cấp chứng chỉ cho các bên cung ứng dịch vụ và các nước sản xuất sản phẩm nông lâm sản. Chính phủ của các nước khối Châu Âu, Châu Mỹ và Châu Úc cũng đang ráo riết xây dựng hành lang pháp lí để kiểm duyệt và cấp chứng chỉ cho các sản phẩm nhập khẩu vào nước họ.

Tại Việt Nam, có 92 công ty trong và ngoài nước kinh doanh trên 21 lĩnh vực và ngành nghề đã kí cam kết vào lộ trình không phá rừng cho tới năm 2020. 21 lĩnh vực bao gồm: Thời trang - trang phục và giày dép, Nông nghiệp, Xây dựng, Mỹ phẩm và chăm sóc cá nhân, Chuỗi bán lẻ thực phẩm, Lâm nghiệp; Nhà cửa - Nội thất và sàn nhà - Vật dụng sửa chữa nhà cửa; Hàng tiêu dùng Thực phẩm, Giấy và bao bì, in ấn và xuất bản, Công nghiệp ô tô - Cao su - Sản xuất ô tô. Các công ty này đóng góp lớn cho GDP quốc gia và phát triển kinh tế địa phương, đồng thời là người mua chủ lực cho các mặt hàng nông sản bao gồm cà phê, gỗ, đỗ tương, thịt gia súc và gia cầm (Phạm và cộng sự 2019).

Tuy nhiên, các doanh nghiệp và chuỗi cung ứng sản phẩm nông lâm sản tại Việt Nam chưa hề được chuẩn bị cả về kiến thức, kĩ năng và quy trình để đáp ứng với các đòi hỏi mới này của thị trường. Nếu hiện trạng này không được nghiên cứu và có phương hướng chuẩn bị lâu dài, ngành nông lâm sản của Việt Nam có nguy cơ không còn cạnh tranh trong thị trường mới, dẫn đến thiệt hại kinh tế to lớn cho nền kinh tế nước nhà.

Chính phủ cần xây dựng hành lang pháp lí để hỗ trợ và giám sát các công ty thực hiện cam kết này, đồng thời nâng cao năng lực cho các bên có liên quan để đón đầu và đáp ứng với yêu cầu của thị trường mới, đảm bảo vị thế vững chắc của các ngành nông lâm sản và đóng góp bền vững của các ngành này vào nền kinh tế quốc dân trong 30 năm sắp tới (Phạm và cộng sự 2019). Việc thực hiện cơ chế giám sát, hướng dẫn và xây dựng các hệ thống cấp chứng chỉ các sản phẩm của Việt Nam không liên quan đến phá rừng và suy thoái rừng sẽ tạo nguồn thu mới cho ngành lâm nghiệp, cũng như nâng cao giá trị sinh thái của các mặt hàng trong 21 ngành nghề kể trên. 


\section{Blue economy và Blue carbon/Kinh tế biển xanh và các-bon từ biển}

Tại các cuộc họp thường niên về Biến đổi khí hậu (COP), vai trò của hệ sinh thái biển trong đó có rừng ngập mặn và tảo biển đối với giảm khí phát thải đã được nhấn mạnh từ năm 1992. Tuy nhiên chỉ đến năm 2013, IPCC mới ra các hướng dẫn cụ thể về việc báo cáo cũng như xây dựng các chính sách liên quan đến bảo vệ hệ sinh thái biển và các-bon từ biển này.

Hướng dẫn bổ sung IPCC Wetlands supplement 2013 cung cấp các phương pháp tính toán phát thải và loại bỏ phát thải $\mathrm{CO}_{2}$ và phổ rộng của các phát thải ngoài $\mathrm{CO}_{2}$ cho đất ngập nước và đất ngập nước ven biển. Hướng dẫn đất ngập nước ven biển cung cấp các phương pháp xác định phát thải và loại bỏ phát thải $\mathrm{CO}_{2}$ cho từng loại hình quản lí đất, phát thải $\mathrm{N}_{2} \mathrm{O}$ từ canh tác thủy hải sản và $\mathrm{CH}_{4}$ từ đất ướt.

Hướng dẫn IPCC về đo đếm phát thải và loại bỏ phát thải từ $\mathrm{CO}_{2}$ đối với các hoạt động cụ thể bao gồm: Quản lí và bảo vệ rừng ngập mặn, Khai thác tài nguyên (ví dụ như xây dựng cầu cảng, xây dựng các khu nuôi trồng thủy hải sản và sản xuất muối), Làm đất ẩm, tái sinh rừng và tạo cảnh quan, đảm bảo hệ thống tưới tiêu (Tanabe 2019).

Tại thời điểm này, theo yêu cầu của UNFCCC, các quốc gia nằm trong Annex 1 bao gồm các quốc gia phát triển được yêu cầu và khuyến khích báo cáo phát thải sử dụng hướng dẫn này (Quyết định 24/ CP.19 của COP). Tuy nhiên, từ năm 2024 trở đi, theo Thỏa thuận Paris, tất cả các quốc gia bao gồm cả nước phát triển và đang phát triển được khuyến khích và yêu cầu dùng các hướng dẫn này (Decision 18/CMA.1 của COP). Nhằm hướng tới mục tiêu này, các nước trên thế giới đang ráo riết xây dựng các chính sách liên quan đến Blue carbon. Năm 2016, trong tổng số 175 quốc gia đã nộp cam kết tự nguyện quốc gia (NDC), có 28 quốc gia đã đề cập về định hướng và chính sách liên quan đến kinh tế biển xanh và các-bon từ biển để giảm thiểu và 59 quốc gia để thích ứng với biển đổi khí hậu (Heer và Landis 2016).

Vấn đề Kinh tế biển xanh (Blue economy) và các-bon từ hệ sinh thái rừng còn mới mẻ và ít được đề cập tại Việt Nam. Tuy nhiên với vai trò to lớn của rừng ngập mặn trong việc đóng góp vào giảm phát thải và hố trợ sự phát triển của nền kinh tế biển xanh, và đồng thời trước yêu cầu của Liên Hợp Quốc về báo cáo về phát thải, Việt Nam cần xem xét và xây dựng các hướng dẫn và chính sách phù hợp. 


\section{Kết luận}

Bài viết này thảo luận 10 xu thế lâm nghiệp quan trọng trên thế giới mà Việt Nam cần xem xét trong quá trình xây dựng chiến lược phát triển lâm nghiệp giai đoạn 2020 - 2050 bao gồm: i) đô thị và những thành phố lâm nghiệp; ii) lâm nghiệp và an sinh xã hội và đóng góp chủ lực cho ngành y tế; (iii) ngành công nghiệp mĩ phẩm làm đẹp và rừng; (iv) kinh doanh côn trùng; (v) thị trường mua bán phá thải và thương mại phát thải; (vi) thuế và thuế giá trị gia tăng của hệ sinh thái rừng; (vii) thị trường chứng khoán, cổ phiếu và trái phiếu rừng; viii) cách tiếp cận về lâm nghiệp và xóa đói giảm nghèo; (ix) thị trường quốc tế, sản xuất và kinh doanh không liên quan đến phá rừng và suy thoái rừng; và $(x)$ kinh tế xanh và các-bon biển. Tiếp cận và xem xét các xu thế không những có thể giúp Việt Nam tiệm cận với những gì đang được xây dựng và tiến hành trên thế giới mà còn mở ra những cánh cửa mới cho việc tìm kiếm nguồn thu mới cho ngành lâm nghiệp. Tuy nhiên, để thực hiện được chính sách nói trên cần có hành lang pháp lí, và xây dựng năng lực cho các bên có liên quan ngay từ bây giờ. Ngoài ra cần tiến hành các nghiên cứu xác định tiềm năng và tác động của chính sách này tới kinh tế, diện tích và chất lượng rừng của Việt Nam để cung cấp các thông tin đầu vào cho các nhà hoạch định chính sách trong thời gian tới. 


\section{Tài liệu tham khảo}

Anderson AB, May PH, and Balick MJ. 1991. The subsidy from nature: palm forests, peasantry, and development on an Amazon frontier. New York: Columbia University Press.

Angelsen A, and Wunder S. 2003. Exploring the forest-poverty link: key concepts, issues and research implications. CIFOR Occasional Paper Number 40. Bogor, Indonesia: Center for International Forestry Research.

Arnold JEM. 2001. Forestry, poverty and aid. CIFOR Occasional Paper No. 33. Bogor, Indonesia: Center for International Forestry Research (CIFOR).

Association of Nature and Forest Therapy Guides and Programs. n.d. 62 forest across Japan. Tokyo: Association of Nature and Forest Therapy Guides and Programs. Accessed 15 November 2019. https://www.fo-society.jp/quarter/cn49/pg937.html.

Association of Nature and Forest Therapy Guides and Programs. n.d. Forest Therapy Guide Training Southern California-Spring 2020. Tokyo: Association of Nature and Forest Therapy Guides and Programs. https://www.natureandforesttherapy.org/event/southern-california-spring-2020.

Association of Nature and Forest Therapy Guides and Programs. Tokyo: Association of Nature and Forest Therapy Guides and Programs. Accessed 15 November 2019. https://www. natureandforesttherapy.org/.

BHP Billiton. 2016. BHP Billiton and IFC collaborate on new Forests Bond. Melbourne: BHP Billiton. Accessed 15 November 2019. https://www.bhp.com/media-and-insights/newsreleases/2016/10/bhp-billiton-and-ifc-collaborate-on-new-forests-bond

Byron RN, and Arnold JEM. 1999. What futures for the people of the tropical forests? World Development 27(5):789-805.

Chambers R, Leach M, and Conroy C. 1993. Trees as Savings and Security for the Rural Poor. Gatekeeper Series Number 3. London: International Institute for Environment and Development. Available online at: http://www.iied.org/pubs/pdfs/ 6025IIED.pdf.

Ellis F. 2000. Rural Livelihoods and Diversity in Developing Countries. Oxford: Oxford University Press.

[EFTI] The European Forest Therapy Institute. Accessed 15 November 2019. http://www. europeanforesttherapyinstitute.com/

FAO. 2019. Forest futures - Sustainable pathways for forests, landscapes and people in the AsiaPacific region. Asia-Pacific Forest Sector Outlook Study III. Bangkok: FAO.

Global Institute of Forest Therapy. Forest City, Canada: GIFT. Accessed 15 November 2019. https:// www.giftoftheforest.com/.

[IFC] International Finance Cooperation. Forest Bond. Washington DC: IFC. Accessed 15 November 2019. https://www.ifc.org/wps/wcm/connect/corp_ext_content/ifc_external_corporate_site/ about+ifc_new/investor+relations/ir-products/forest_bonds.

[IFC]. 2016a. Presentation: Forest Bond. Washington DC: IFC. Accessed 15 November 2019. https://www.ifc.org/wps/wcm/connect/bb81f7e5-ea3e-4a78-b1c6-3b9c810f62fe/ FINAL+Forests+Bond+Investor+Presentation+10-5_pdf.pdf?MOD=AJPERES\&CVID=IxOnv97.

[IFC]. 2016b. FactS sheet: Forest Bond. Washington DC: IFC. Accessed 15 November 2019. https://www.ifc.org/wps/wcm/connect/982eb7ef-1daa-49ca-b9c0-e6f3a2ddcd88/ FINAL+Forests+Bond+Factsheet+10-5. pdf?MOD=AJsPERES\&CVID=IxS1w0E.

Herr D, and Landis E. 2016. Coastal blue carbon ecosystems. Opportunities for Nationally Determined Contributions. Policy Brief. Gland, Switzerland: IUCN and Washington DC, USA: TNC.

Hickey GM, Pouliot M, Smith-Hall C, Wunder S, \& Nielsen MR. 2016. Quantifying the economic contribution of wild food harvests to rural livelihoods: A global-comparative analysis. Food Policy 62:122-132.

International Society of Nature and Forest Medicine. 2015. Forest Policy and Forest Healing in the Republic of Korea. Osaka: International Society of Nature and Forest Medicine. Accessed 15 November 2019. https://www.infom.org/news/2015/10/10.html. 
Konijnendijk CC, Ricard RM, Kenney A, \& Randrup TB. 2006. Defining urban forestry-A comparative perspective of North America and Europe. Urban Forestry \& Urban Greening 4(3-4):93-103. https://doi.org/10.1016/j.ufug.2005.11.003.

McSweeney K. 2004. Forest product sale as natural insurance: the effects of household characteristics and the nature of shock in eastern Honduras. Society and Natural Resources 17(1):39-56.

Ministry of Finance - The Republic of Chile. 2019. Green Bond Framework. Santiago, Chile: Ministry of Finance. https://www.climatebonds.net/files/files/Chile\%20Sovereign\%20Green\%20Bond\%20 Framework.pdf.

Nature and Therapy UK. Dartington, UK: Nature and Therapy UK. Accessed 15 November 2019. http://natureandtherapy.co.uk/.

Pacific Forest Trust. n.d. California's Cap-And-Trade Extension Holds Promise for Forests. San Francisco: Pacific Forest Trust. https://www.pacificforest.org/ca-capandtrade-holds-promiseforests/.

Pattanayak SK, and Sills EO. 2001. Do tropical forests provide natural insurance? The microeconomics of non-timber forest product collection in the Brazilian Amazon. Land Economics 77(4):595-612.

Pham TT, Nguyen DT, Dao TLC, Hoang TL. 2019. Chuẩn bị cho Việt Nam sã̃n sàng với luật chơi mới trên thị trường quốc tế- sản xuất và kinh doanh không liên quan tới phá rừng và suy thoái rừng. CIFOR Working Paper no. 253. Bogor, Indonesia: Center for International Forestry Research (CIFOR).

Ruíz PM, Belcher B, Fu M, and Yang X. 2004. Looking through the bamboo curtain: an analysis of the changing role of forest and farm income in rural livelihoods in China. International Forestry Review 6(3-4):306-316.

Sunderlin W, Dewi S, Puntodewo A, Müller D, Angelsen A, \& Epprecht M. 2008. Why forests are important for global poverty alleviation: a spatial explanation. Ecology and Society, 13(2).

Takasaki Y, Barham BL, and Coomes OT. 2004. Risk coping strategies in tropical forests: floods, illnesses and resource extraction. Environment and Development Economics 9(2):203-224.

Tanabe K. 2019. Phát biểu tại Workshop on Incorporating Blue Carbon into Nationally Determined Contributions - 8-10 July 2019. Hanoi, Vietnam.

Vedeld P, Angelsen A, Sjaastad E, and Kobugabe Berg G. 2004. Counting on the environment: forest incomes and the rural poor. Environmental Economics Series Number 98. Washington DC: World Bank.

World Bank. 2000. World Development Report 2000/2001: Attacking Poverty. Washington DC: World Bank.

Zwick S. n.d. Why indigenous people should care about California's Cap-and-Trade program. Ecosystem Marketplace. Accessed 15 November 2019. https://www.ecosystemmarketplace.com/ articles/why-indigenous-people-should-care-about-californias-cap-and-trade-program/. 

Các báo cáo chuyên đề của CIFOR bao gồm các kết quả nghiên cứu sơ bộ hoặc nâng cao về các vấn đề về rừng ở các khu vực nhiệt đới và cần được công bố vào thời điểm thích hợp để tạo ra và thúc đẩy các cuộc thảo luận. Nội dung báo cáo đã được rà soát nội bộ nhưng chưa trải qua quá trình bình duyệt từ các chuyên gia bền ngoài tổ chức.

Bài viết này thảo luận 10 xu thế lâm nghiệp quan trọng trên thế giới mà Việt Nam cần xem xét trong quá trình xây dựng chiến lược phát triển lâm nghiệp giai đoạn 2020 - 2050 bao gồm: i) đô thị và những thành phố lâm nghiệp; ii) lâm nghiệp và an sinh xã hội và đóng góp chủ lực cho ngành y tế; (iii) ngành công nghiệp mĩ phẩm làm đẹp và rừng; (iv) kinh doanh côn trùng; (v) thị trường mua bán phá thải và thương mại phát thải; (vi) thuế và thuế gia trị gia tăng của hệ sinh thái rừng; (vii) thị trường chứng khoán, cổ phiếu và trái phiếu rừng; viii) cách tiếp cận về lâm nghiệp và xóa đói giảm nghèo; (ix) thị trường quốc tế, sản xuất và kinh doanh không liên quan đến phá rừng và suy thoái rừng; và $(x)$ kinh tế xanh và các-bon biển. Tiếp cận và xem xét các xu thế không những có thể giúp Việt Nam tiệm cận với những gì đang được xây dựng và tiến hành trên thế giới mà còn mở ra những cánh cửa mới cho tìm kiếm nguồn thu mới cho ngành lâm nghiệp. Tuy nhiên, để thực hiện được chính sách nói trên cần có hành lang pháp lí, xây dựng năng lực cho các bên có liên quan ngay từ bây giờ. Ngoài ra cần tiến hành các nghiên cứu xác định tiềm năng và tác động của chính sách này tới kinh tế, diện tích và chất lượng rừng của Việt Nam để cung cấp các thông tin đầu vào cho các nhà hoạch định chính sách trong thời gian tới.

\begin{tabular}{|l|l|l|l|l|l} 
Chương trình nghiên cứu của CGIAR về Rừng, Cây gỗ và Nông lâm kết hợp (FTA) là chương trình \\
phát triển nghiên cứu lớn nhất thế giới nhằm nâng cao vai trò của rừng, cây gỗ và nông lâm kêtt hợp \\
với mục tiêu phát triển bền vững và đảm bảo lương thực để ứng phó với biến đổi khí hậu. CIFOR \\
chủ trì các nghiên cứu FTA trong mối quan hệ đối tác chiến lược với Bioversity International, CATIE, \\
CIRAD, INBAR, ICRAF và TBI. \\
Nghiên cứu này được hỗ trợ bởi Quỹ đối tác CGIAR: cigar.org/funders/ \\
$\begin{array}{l}\text { PROGRAM on } \\
\text { Forests, Trees and }\end{array}$
\end{tabular}

cifor.org | forestsnews.cifor.org

\section{Norad USAID}

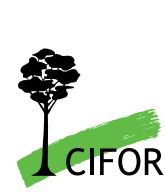

Trung tâm Nghiên cứu Lâm nghiệp Quốc tế (CIFOR)

CIFOR thúc đẩy sự phồn vinh của nhân loại, cải thiện bảo vệ môi trường và thúc đẩy sự bình đẳng thông qua tiến hành các nghiên cứu sáng tạo, nâng cao năng lực của các bên đối tác, tích cực tham gia đối thoại với các bên liên quan để hỗ trợ định hình chính sách và thực tiễn tác động tới rừng và con người. CIFOR là tổ chức nghiên cứu thuộc liên minh CGIAR và chủ trì các chương trình nghiên cứu của CGIAR về Rừng, Cây gỗ và Nông lâm kết hợp (FTA). Trụ sở chính của CIFOR đặt tại Bogor, Indonesia và các văn phòng của CIFOR có mặt tại Nairobi, Kenya; Yaounde, Cameroon; Lima, Peru và Bonn, Germany. 